\title{
Abstracts of Articles
}

\section{"Agricultural Expansion as a Tool of Population Redistribution in Southeast Asia" by RODOLPHE DE KONINCK and STEVE DÉRY}

Throughout history and throughout most major regions of the world, the expansion of agricultural land has served as a tool of population redistribution and has also played a key role in the formation and consolidation of States. This appears particularly true in twentieth-century Southeast Asia, as can be observed from case studies of the Philippines, Indonesia, Vietnam and Thailand developed in this article, and may contribute to the originality and dynamism of State formation in the region.

\section{"Constructing a China Metaphor: Sukarno's Perception of the PRC and Indonesia's Political Transformation" by HONG LIU}

Throughout Sukarno's long and colourful political career, China constituted one of the central objects in his construction of the outside world. What did the PRC stand for in his intellectual and political imagination? How relevant was Sukarno's China perception to the evolution of his own socio-political thought? This paper suggests that Sukarno's favourable view of the PRC reflected more of his predispositions about Indonesia than it did Chinese realities. China as seen through Sukarno's eyes became the point of reference for both intellectual judgement and political thinking. Furthermore, Sukarno employed his perception of China as a cultural metaphor, social symbol, and political model in his drive to establish and consolidate the Guided Democracy regime.

\section{"Contested Time and Place: Constructions of History in Todo, Manggarai (Western Flores, Indonesia)" by MARIBETH ERB}

The recent rebuilding of the house of the clan from which a "king" of Manggarai was chosen during direct Dutch rule on the island of Flores in the Indonesian archipelago has brought to light several different histories of that clan's rise to power and the meaning of the house in those histories. This paper explores the contestation over both time and place in Todo, Manggarai, relating them to people's present-day concerns.

\section{"On the Contemporary Uses of Colonial History and the Legitimation of Political Status in Archipelagic Southeast Seram" by ROY ELLEN}

Drawing upon data from the Seram Laut and Gorom archipelagoes, this paper examines how contemporary rulers legitimate their rights by asserting links with sources of traditional authority. In particular, it is argued that archaic titles remain important because the colonial period stabilized the relationship between domains, and because such titles thus provide a means of validating claims to resources, 
combating state incursions and competing for influence. The possession of old documents supports such claims by confirming them in writing, but also by being old "things" linked to the person of the ruler.

"The Frustrations of Development: British Business and the Late Colonial State in Malaya, 1945-57' by NICHOLAS J. WHITE

The article reassesses the economic role of the late colonial state in Malaya. It seeks to dispel the view that the colonial government served British business interests, and that broad-based development policies only followed independence in 1957. Rather the developmentalist orientation of the state began earlier in the 1940s, and was not fully in accordance with existing economic interests.

\section{"Endangered Identity: Kadazan or Dusun in Sabah (East Malaysia)" by ANTHONY REID}

The dominant indigenous community of Sabah, East Malaysia, came late to the process of imagining itself as a modern political community. Its difficulties in identifying an acceptable name, boundaries and symbols for itself since entering Malaysia in 1963 provide an interesting case study of identity formation without the benefit of a long written tradition.

"Free France, the British Government and the Future of French Indo-China, 194045" by MARTIN THOMAS

This article traces the development of Gaullist and British policies with respect to Indo-China from the fall of France in 1940 to the end of the Far Eastern war five years later. Directed toward restoring imperial influence in Southeast Asia, these policies were sophisticated and complex, but they bore little fruit owing to the relative strategic insignificance of Indo-China during this period, and the imperatives of Anglo-American relations. 